Proc. Estonian Acad. Sci. Geol., 1999, 48, 3, 123-139

\title{
EESTI \\ RAAMATUKOGU \\ COMMUNITY STRUCTURE AND SUCCESSION OF BALTOSCANDIAN EARLY PALAEOZOIC STROMATOPOROIDS
}

\author{
Heldur NESTOR
}

Institute of Geology, Tallinn Technical University, Estonia pst. 7, 10143 Tallinn, Estonia; hnestor@gi.ee

Received 22 February 1999, in revised form 31 March 1999

\begin{abstract}
Twenty-eight stromatoporoid communities are defined, spreading in Upper Ordovician and Silurian deposits of Estonia, Sweden (Gotland), and Norway (Oslo Region). The communities are linked to the Standard Benthic Assemblages (BA) after Boucot (Evolution and Extinction Rate Controls, 1975). Successive stromatoporoid faunas consist of imperfectly delimited lateral communities of different stratigraphical range and taxonomical diversity. The richest communities occur in the reef (shoal) facies corresponding to BA2. These have the shortest stratigraphical range and are laterally replaced by less diverse long-range communities.
\end{abstract}

Key words: community, succession, stromatoporoid, Ordovician, Silurian, Estonia, Sweden, Norway.

\section{INTRODUCTION}

Due to the complete, almost continuous carbonate sequences rich in various benthic fossils, and detailed taxonomical research of stromatoporoids, the BalticScandinavian region offers the best opportunities for elaboration of the biostratigraphical standard of the Late Ordovician and Silurian stromatoporoids, taking into account both the stratigraphical succession and lateral pattern of communities.

Estonian stromatoporoids have been taxonomically studied by Riabinin (1951) and Nestor $(1964,1966)$, those of Gotland by Mori $(1968,1970)$. Mori also described Silurian stromatoporoids from the Öved-Ramsåsa Group (Ludlow) of Scania (Mori, 1969) and from the Oslo Region of Norway (Mori, 1978). Webby (1979) described the Ordovician, middle Caradoc stromatoporoids from the Mjøsa district in Norway. Nestor (in Kaljo et al., 1963) identified a few specimens of stromatoporoids from the Ashgill of the Ringerike area. The listed 
publications serve as the main source on the distribution of stromatoporoids in Baltoscandia.

The author has published a paper on the Wenlock stromatoporoid communities of Estonia and Gotland Island (Nestor, 1982), and a preliminary note on the succession of the Ordovician and Silurian stromatoporoid communities, mainly based on the Estonian data (Nestor, 1990). The note was supplemented by a full list of taxa established in the East Baltic area, including unpublished identifications of stromatoporoids from the drill cores of southern Estonia, Latvia, and Lithuania. However, the communities remained undefined and uncharacterized, which diminished their value for correlation purposes. The aim of the present paper is to amend this shortcoming. Besides, the data from Sweden and Norway are included, giving a complete picture of the community pattern in Baltoscandia. During short field trips to Gotland (1994) and Oslo area (1995, 1997), several main stromatoporoid localities were examined, as a result of which the lateral and stratigraphical positioning of the stromatoporoid communities was improved.

\section{LATERAL COMMUNITIES}

In Nestor (1990) the lateral stromatoporoid communities were linked to the facies model of the Baltic Silurian Basin. Due to disputable terminology and interpretation of the carbonate facies and environments, there arose a need for a more universal framework for positioning the stromatoporoid communities. Therefore in the present work they are bound to the Standard Benthic Assemblages (further BA) after Boucot (1975). The correspondence between the main facies belts of the Baltic Silurian Basin and the Standard Benthic Assemblages is shown in Fig. 1.

The ecological niche of stromatoporoids was roughly restricted to the euphotic zone of the normal-marine carbonate shelf (platform) (Nestor, 1977, 1984). The richest and the most diverse stromatoporoid association is connected with the sediments of the high-energy, shoal (middle shelf) facies belt, represented in fossil record by coral-stromatoporoid boundstones, skeletal and coquinoid grainstones, and rudstones. The position of this belt corresponds to BA2. Stromatoporoids are rather numerous but less diverse also in the deposits of the moderate- to low-energy open shelf, which are represented by nodular skeletal pack- to wackestones (biomicritic limestones) containing BA3 (above storm-wave base) and BA4 (below storm-wave base).

Rare stromatoporoids occur in the inner, restricted shelf (lagoonal) sediments with specific BA1 fauna. In geological record this facies belt is represented by argillaceous wackestones interbedding with different primary dolostones. An impoverished taxonomical content characterizes also the communities which correspond to the transition between BA4 and BA5 (BA4/5) and are distributed in calcareous marlstones that formed at the outer edge of the carbonate shelf. The 


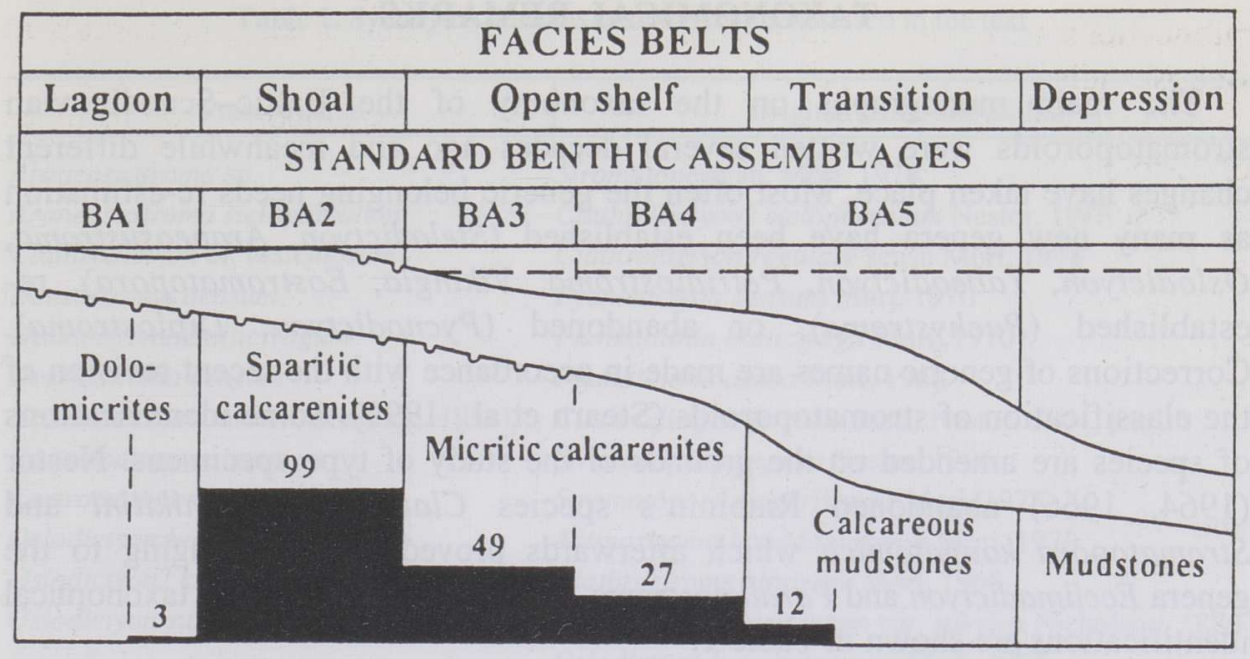

Fig. 1. Mutual position of the main facies belts of the Palaeobaltic basin (after Nestor, 1990) and Standard Benthic Assemblages (BA), with the distribution of lithogenetic types of sediments and bar chart of the lateral distribution of stromatoporoid species. Numbers show the quantity of species recorded from the corresponding benthic assemblage.

lateral communities of stromatoporoids are rather poorly delimited. The BA3 and BA4 communities do not show principal differences except certain decrease in the variability of the latter. The communities corresponding to BA2, particularly the reef communities, usually contain the most common elements of the coeval open shelf (BA3-BA4) communities, but in addition they include some specific taxa which have a shorter stratigraphical range and enable more detailed biozonation of the rocks of the shoal facies belt in comparison with other belts. The marginal, BA1/2 and BA4/5 communities stand out with very few and longrange species.

The joint, spatial and temporal distribution pattern of the stromatoporoid communities is shown in Fig. 2. More distinct boundaries between the communities are designated by a solid line, transitional or obscure ones by a dashed line. The lithostratigraphical columns are mostly compiled of the units containing stromatoporoids. The names of the units lacking stromatoporoids are in square brackets. In the Estonian column the Ventspils Formation from Latvia and Lithuania is added. The column was compiled after Männil \& Meidla (1994) and Nestor (1997) from the stratigraphical units distributed on West Estonian islands and in northern central Estonia. The column of Gotland contains traditional units, including the Öved-Ramsåsa Group from Scania. The stratigraphical succession of the Oslo Region is mainly based on the sequence of the Ringerike area with the Solvik Formation from the Oslo-Asker district and the Mjøsa Formation from Hamar (after Worsley et al., 1983; Owen et al., 1990). 


\section{TAXONOMICAL REMARKS}

The main monographs on the taxonomy of the Baltic-Scandinavian stromatoporoids were written several decades ago and meanwhile different changes have taken place. Most often the generic belonging needs re-estimation as many new genera have been established (Stelodictyon, Araneosustroma, Oslodictyon, Yabeodictyon, Petridiostroma, Vikingia, Eostromatopora), reestablished (Pachystroma), or abandoned (Pycnodictyon, Diplostroma). Corrections of generic names are made in accordance with the recent revision of the classification of stromatoporoids (Stearn et al., 1999). Some identifications of species are amended on the grounds of the study of type specimens. Nestor (1964, 1966) abandoned Riabinin's species Clathrodictyon nikitini and Stromatopora kaugatomica which afterwards proved valid, belonging to the genera Ecclimadictyon and Parallelostroma, respectively. The revised taxonomical identifications are shown in Table 1.

\section{ORDOVICIAN COMMUNITIES}

The Stromatocerium sakuense Community. A poor middle Caradoc stromatoporoid community in BA2 position. Includes Stromatocerium sakuense Nestor and Stromatocerium canadense (Nicholson). Occurs in intercalating silty marlstones and pack- to grainstones of the Saku Member of the Oandu Regional Stage in northern Estonia. Type locality - an old quarry near the settlement of Saku. Stromatocerium cf. sakuense has been described from the Mangasei Group of the Siberian Platform (Nestor, 1976), Stromatocerium canadense from the Black River and Trenton stages of the North American Midcontinent (Galloway \& St. Jean, 1961).

The Pachystylostroma mammillatum Community. A low-diversity middle Caradoc community corresponding to BA2. Consists of Labechia bergevikensis, Pachystylostroma mammillatum, P. surculum, Pachystylostroma sp., and Radiostroma tenue (Webby, 1979). Occurs in reef limestones of the Mjøsa Formation in the Lake Mjøsa district, Norway. Type area - foreshore and abandoned quarries at Bergevika, Helgøya Island. The community is probably slightly younger than the Stromatocerium sakuense Community. Unknown in other areas.

The Clathrodictyon vormsiense Community. A poor, dispersed early Ashgill community in BA3 position. Besides rare Clathrodictyon vormsiense Riabinin, it includes poorly preserved, undeterminable labechiids, described by Riabinin (1951) as Stromatopora dagoensis. Rare, scattered occurrences of these species are recorded from the nodular biomicritic limestones of the Kõrgessaare Formation of the Vormsi Stage on Hiiumaa and Vormsi islands. Type locality an old quarry at Kõrgessaare, Hiiumaa. The community is not known from other regions. 
Table 1. Synonyms of some taxonomical names used in the text

\begin{tabular}{|c|c|}
\hline Present name & Original name and author \\
\hline Araneosustroma sp. & Stromatopora sp. Mori, 1978 \\
\hline Araneosustroma stelliparratum & Clathrodictyon? stelliparratum Nestor, 1966 \\
\hline Clathrodictyon cf. vesiculosum & Clathrodictyon regulare sensu Mori, 1978 \\
\hline Densastroma densum & Pycnodictyon densum Mori, 1970 \\
\hline Desmostroma balticivagum & Plumatalinia balticivaga Mori, 1970 \\
\hline Desmostroma densum & Plumatalinia densa Mori, 1968 \\
\hline Ecclimadictyon nikitini (Riabinin, 1951) & Clathrodictyon boreale sensu Nestor, 1964, partim \\
\hline Eostromatopora impexa & Stromatopora impexa Nestor, 1966 \\
\hline Eostromatopora ringerikensis & Stromatopora ringerikensis Mori, 1978 \\
\hline Oslodictyon botvaldavikense & Actinostroma botvaldavikense Mori, 1970 \\
\hline Oslodictyon? klintense & Clathrostroma klintense Mori, 1968 \\
\hline Oslodictyon suevicum & Actinostroma intertextum var. suevica Nicholson, 1886 \\
\hline “ & Oslodictyon henningsmoeni Mori, 1978 \\
\hline Pachystroma elegans & Stromatopora elegans Rosen, 1867 \\
\hline Pachystroma hesslandi & Pseudolabechia hesslandi Mori, 1968 \\
\hline $\begin{array}{l}\text { Parallelostroma kaugatomicum (Riabinin, } \\
\text { 1951) }\end{array}$ & Parallelostroma typicum sensu Nestor, 1966, partim \\
\hline Petridiostroma cf. argutulum & Clathrodictyon cf. argutulum sensu Mori, 1968 \\
\hline Petridiostroma convictum & Clathrodictyon convictum Yavorsky, 1929 \\
\hline Petridiostroma regulare & Stromatopora regularis Rosen, 1867 \\
\hline Petridiostroma simplex & Simplexodictyon simplex Nestor, 1966 \\
\hline Plectostroma lepidum & Labechia lepida Mori, 1970 \\
\hline Stelodictyon conodigitatum & Clathrodictyon regulare var. conodigitata Riabinin, 1951 \\
\hline Stelodictyon? djupvikense & Clathrodictyon djupvikense Mori, 1970 \\
\hline Stelodictyon mammillatum & Stromatopora mammillata Schmidt, 1858 \\
\hline Stelodictyon striatellum & Stromatopora striatella d'Orbigny, 1849 \\
\hline Simplexodictyon podolicum & Diplostroma yavorskyi Nestor, 1966 \\
\hline Simplexodictyon validum & Diplostroma validum Nestor, 1966 \\
\hline “ & Diplostroma yavorskyi sensu Mori, 1968 \\
\hline
\end{tabular}

Syringostromella? aspectabilis (Yavorsky, Stromatopora discoidea sensu Mori, 1978 1961)

Yabeodictyon quebecense

Actinodictyon quebecense Stearn et Hubert, 1966

The Clathrodictyon microundulatum Community. A low-diversity, dispersed middle Ashgill community in BA3-BA4 position. Besides the nominal species $C$. microundulatum Nestor, it contains rare Stromatocerium canadense (Nicholson), Cystostroma estoniense Nestor, and Plumatalinia ferax Nestor. The community has a scattered distribution in micritic limestones and mud-mounds of the Moe Formation, and in argillaceous biomicritic limestones of the Adila Formation of the Pirgu Stage in northern Estonia. Type area - the Noarootsi Peninsula in western Estonia. The author has identified some elements of the community (Clathrodictyon microundulatum and Stromatocerium canadense) from stratified 
limestones of the Bønsnes Formation (?) at Stamnestangen, Ringerike, Norway (see also Kaljo et al., 1963). Uncertain records of the nominal species (Clathrodictyon cf. microundulatum) come from the Vandon Limestone of the Cliefden Caves Group, New South Wales (Webby, 1969) and from the Baiyanhushan Formation in Inner Mongolia, China (Lin \& Webby, 1988).

The Stylostroma-Pachystylostroma Community. A specific middle-late Ashgill reef community corresponding to BA2. Consists of new, undescribed species of Stylostroma, Pachystylostroma, Labechia, and Ecclimadictyon, which were collected by the author from massive reef limestone in foreshore cliff at Stamnestangen, Ringerike. The exact stratigraphical position of the community is problematic (?Langøyene Formation), but probably it lies above the Clathrodictyon microundulatum Community.

The Clathrodictyon gregale Community. A moderately diverse late Ashgill community corresponding to BA2. Includes numerous Clathrodictyon gregale Nestor, C. zonatum Nestor, Ecclimadictyon porkuni (Riabinin), E. koigiense Nestor, and rare Pachystylostroma fragosum Nestor and Stelodictyon mammillatum (Schmidt). The community is characteristic of the biohermal and pelmatozoan limestones of the Ärina Formation, Porkuni Stage in Estonia. Type locality - old Porkuni quarry in northern central Estonia. In Norway the presence of the community is problematic. Stelodictyon cf. mammillatum and Ecclimadictyon $\mathrm{cf}$. koigiense have been established from the Shihuichang Formation of Qinghai Province, China (Lin \& Webby, 1988).

\section{LLANDOVERY COMMUNITIES}

The Clathrodictyon boreale-Ecclimadictyon microvesiculosum Community. A widespread lowermost Silurian (Rhuddanian-Aeronian) community spanning BA2-BA4 positions. Includes many closely related species of Clathrodictyon and Ecclimadictyon [Clathrodictyon boreale Riabinin, C. sulevi Nestor, C. kudriavzevi Riabinin, C. lennuki Nestor, Ecclimadictyon microvesiculosum (Riabinin), E. nikitini (Riabinin), E. porkuni (Riabinin), E. laminaeungulatum (Riabinin)], and rare labechiids (Pachystylostroma rosensteinae Nestor, $P$. contractum Nestor, Labechia venusta Nestor). In Estonia the community spreads in various lithofacies from the nodular biomicritic limestones of the open shelf to the coquinoid and pelletal limestones of the shoal belt which are represented by the Varbola, Tamsalu, and Nurmekund formations of the Juuru and Raikküla stages. Type locality - the well in the ancient stronghold of Varbola, northern central Estonia. The elements of this community, particularly Clathrodictyon boreale and Ecclimadictyon microvesiculosum, are known from many places all over the world (e.g. Becscie Formation of Anticosti Island, Canada).

The Forolinia brevis Community. A marginal, single-taxon early to middle Llandovery community in BA4/5 position, laterally replacing the Clathrodictyon boreale-Ecclimadictyon microvesiculosum Community. Rare specimens of the 


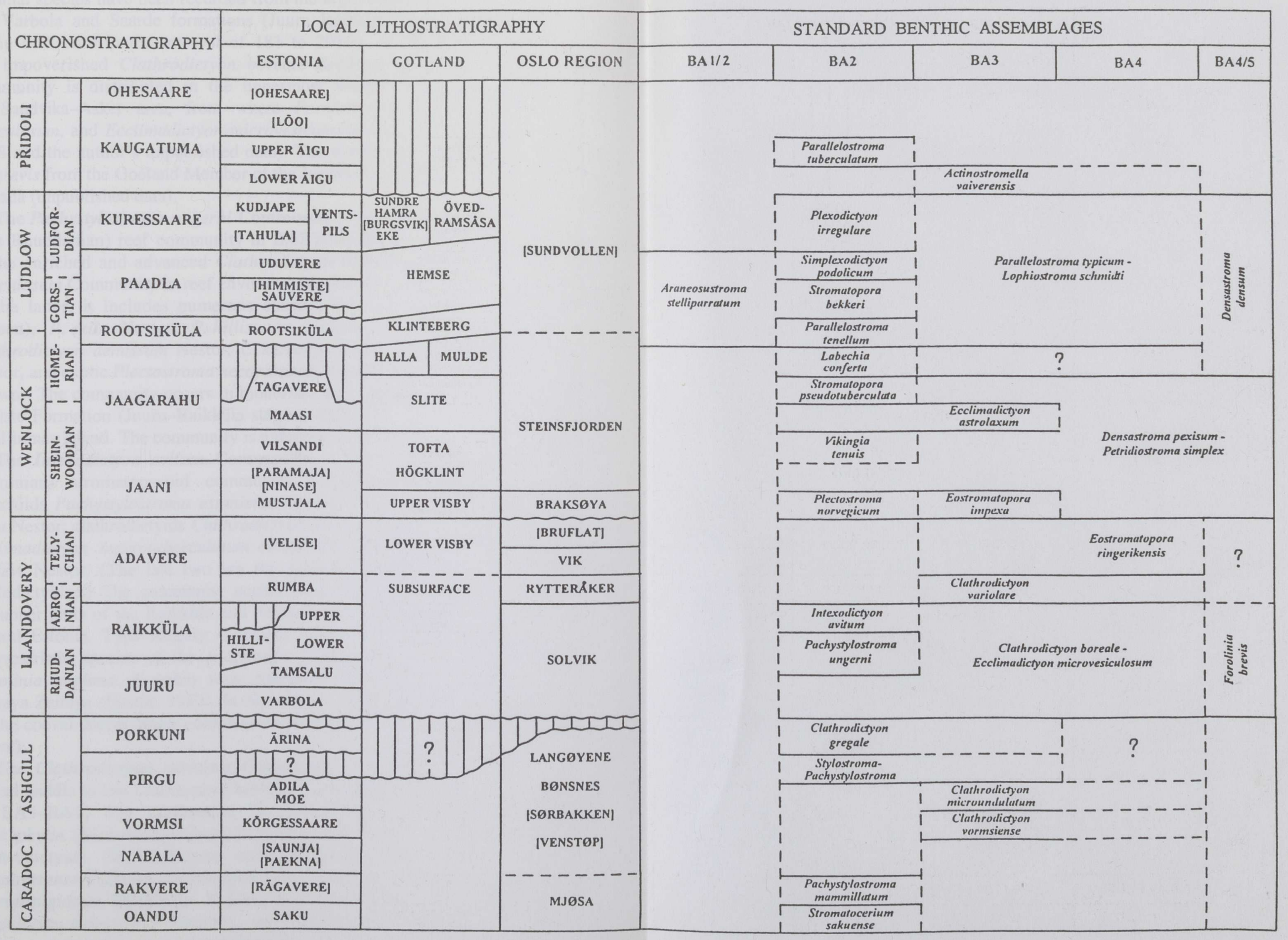

Fig. 2. Stratigraphical succession and lateral position of stromatoporoid communities in the Early Palaeozoic sequences of Baltoscandia. 
nominal species have been recorded from the argillaceous nodular limestones of the Varbola and Saarde formations (Juuru-Raikküla stages). Type section Pärnu drill core in the interval of 181 to $201 \mathrm{~m}$. A mixed Forolinia brevis and impoverished Clathrodictyon boreale-Ecclimadictyon microvesiculosum community is distributed in the uppermost Solvik Formation (6c beds) in the Sandvika-Asker area, from where Forolinia brevis, Clathrodictyon cf. vesiculosum, and Ecclimadictyon microvesiculosum have been identified (Mori, 1978 and the author's unpublished data). The author also determined Forolinia cf. brevis from the Goéland Member of the Jupiter Formation of Anticosti Island, Canada (unpublished data).

The Pachystylostroma ungerni Community. A very diverse early Llandovery (late Rhuddanian) reef community in BA2 position, representing an analogue of the enriched and advanced Clathrodictyon boreale-Ecclimadictyon microvesiculosum Community in reef environments. Besides the characteristic species of the latter, it includes numerous specific taxa: Pachystylostroma ungerni (Rosen), P. exile Nestor, P. hillistense Nestor, Forolinia lineata Nestor, Clathrodictyon demissum Nestor, C. sarvense Nestor, Ecclimadictyon pandum Nestor, and exotic Plectostroma necopinatum Nestor (the earliest actinostromatid known). The community occurs in biohermal and pelmatozoan limestones of the Hilliste Formation (Juuru-Raikküla stages). Type locality - old Hilleste quarry on Hiiumaa Island. The community is unknown in other areas.

The Intexodictyon avitum Community. A rather rich middle Llandovery (Aeronian) stromatoporoid community corresponding to BA2. Includes labechiids Pachystylostroma estoniense Nestor, P. opiparum Nestor, Forolinia paka Nestor; clathrodictyids Clathrodictyon clivosum Nestor, C. turritum Nestor, Ecclimadictyon macrotuberculatum (Riabinin), Intexodictyon avitum Nestor, I. olevi Nestor. (The last two are the earliest representatives of the family Atelodictyidae.) The community occurs in coral-stromatoporoid limestones of the upper parts of the Raikküla and Nurmekund formations (Raikküla Stage) in central Estonia. Type locality - ancient inland cliff Laukna-Pakamägi. Some characteristic species of the community (Ecclimadictyon macrotuberculatum, Forolinia implana, F. paka) were recognized in the Perseisk Formation of Novaya Zemlya (Nestor, 1983). In Norway the community is probably replaced by the coeval deeper-water communities at the top of the Solvik Formation (see above).

The Clathrodictyon variolare Community. An extremely rich and widespread middle to late Llandovery (Aeronian-Telychian) community corresponding to BA3-BA4. The community is represented by labechiids Forolinia pachyphylla (Nicholson), Rosenella dentata (Rosen), R. tuberculata Riabinin; clathrodictyids Clathrodictyon variolare (Rosen), C. delicatulum Nestor, C. adaverense Riabinin, Stelodictyon conodigitatum (Riabinin), Ecclimadictyon microfastigiatum (Riabinin), E. fastigiatum (Nicholson), E. arcuatum Nestor, Oslodictyon suevicum (Nicholson), and Petridiostroma regulare (Rosen) - the earliest representative of Gerronostromatidae. One of the earliest syringostromatids, 
Pachystroma elegans (Rosen), is also present. In Estonia the community occurs in nodular, biomicritic limestones of the Rumba Formation (Adavere Stage) with tempestitic interlayers and scattered shells of Pentamerus oblongus. Type locality - an old quarry at Päri, western Estonia. In Norway several species of the community (Clathrodictyon variolare, Ecclimadictyon fastigiatum, E. microfastigiatum, Stelodictyon conodigitatum, Oslodictyon suevicum) occur in the Rytteråker Formation of Oslo-Asker and Ringerike districts. The author has identified diagnostic elements of the community (Clathrodictyon variolare, Ecclimadictyon cf. fastigiatum, Petridiostroma cf. regulare) from the Perseisk Formation of Novaya Zemlya (Nestor, 1983). The author's unpublished determinations of the characteristic species come from the Jupiter Formation of Anticosti Island, Canada (Clathrodictyon variolare, Ecclimadictyon fastigiatum), from the La Porte City Formation of Iowa, USA (Ecclimadictyon fastigiatum, Stelodictyon conodigitatum, Oslodictyon suevicum), and from the Red Mountain Formation of Alabama (Stelodictyon conodigitatum).

The Eostromatopora ringerikensis Community. A poor, dispersed latest Llandovery (late Telychian) community in BA4 position. Includes Eostromatopora ringerikensis (Mori) (the first record of the Order Stromatoporida) and longrange Petridiostroma simplex (Nestor). In Baltoscandia it is only known from nodular, shaly limestones of the Vik Formation in the Ringerike district of Norway. Coeval, more diverse stromatoporoid communities have been established in the Coonnamna Formation of northwestern Ireland (Nestor, 1999) and from the topmost Baillarge Formation of Baffin Island, arctic Canada (Petryk, 1967). In Estonia the community is lacking because of too deep-water conditions at the end of the Llandovery.

\section{WENLOCK COMMUNITIES}

The Eostromatopora impexa Community. The earliest Wenlock community in BA3 position. Consists of specific Clathrodictyon linnarssoni Nicholson, C. affabile Nestor, Pachystroma hesslandi (Mori), Eostromatopora impexa (Nestor), as well as long-range, widespread species Petridiostroma simplex (Nestor) and Densastroma pexisum (Yavorsky). The community is distributed in interbedded biomicritic limestones and marlstones of the uppermost Mustjala Member of the Jaani Formation (Stage) in Estonia and in the Upper Visby Beds of Gotland. Type locality - Liiva cliff on the north coast of Saaremaa. The community is unknown in other regions.

The Plectostroma norvegicum Community. A poor early Wenlock (early Sheinwoodian) community corresponding to BA2. Consists of Plectostroma norvegicum Mori, Clathrodictyon cf. crickmayi Parks, and Syringostromella cf. aspectabilis (Yavorsky). It is distributed in the Braksøya Formation in the Ringerike area and is represented by massive reef and bioclastic limestones. 
Type locality - Braksøya Island in Lake Ringerike. The community is probably contemporaneous with the Eostromatopora impexa Community. Similar species have been reported from the La Vieille Formation in the Gaspe Peninsula, Quebec (Clathrodictyon crickmayi - Parks, 1933) and from the Hakom Formation of the Siberian Platform (Syringostromella aspectabilis - Nestor, 1976).

The Vikingia tenuis Community. A highly specialized early Wenlock (middle Sheinwoodian) reef community corresponding to BA2. Vikingia tenuis (Nestor) is the dominating species; V. vikingi (Nestor), Actinodictyon nestori Mori, and Syringostromella? yavorskyi Mori are the accessory elements. The community is characteristic of the reefs in the Vilsandi Beds of the Jaagarahu Formation (Stage) in Estonia and of the Högklint reefs and Tofta algalstromatoporoid limestones on Gotland. Type locality - an old quarry at Jaagarahu in western Saaremaa.

The Ecclimadictyon astrolaxum Community. A diverse early Wenlock (late Sheinwoodian) community in BA2-BA3 position. It includes Ecclimadictyon astrolaxum Nestor, E. macrotuberculatum (Riabinin), E. robustum Nestor, Simplexodictyon validum (Nestor), and Syringostromella tenerrima Mori, besides long-range, widespread Densastroma pexisum (Yavorsky) and Petridiostroma simplex (Nestor). The community spreads in the Maasi Beds of the Jaagarahu Formation (Stage) in Estonia and in the lower part of the Slite Beds on Gotland, which are represented by various bioclastic limestones and marlstones enclosing small bioherms. Type locality - ditches at Sepise in western Saaremaa. Nestor (1976) has identified Simplexodictyon validum from the Hakom Formation on the Moiero River, Siberian Platform. Ecclimadictyon robustum has been recorded (Bogoyavlenskaya, 1973) from the Voronin and Pavdinsk beds in the Urals.

The Stromatopora pseudotuberculata Community. A diverse Wenlock (early Homerian) community corresponding to BA2. Besides nominal species, described by Mori (1968) as Stromatopora cf. pseudotuberculata Riabinin, it contains Plectostroma guticum Mori, Densastroma aff. podolicum (Yavorsky), Ecclimadictyon astrolaxum Nestor, Yabeodictyon balticum Mori, Clathrodictyon cf. argutulum Khalfina, Oslodictyon klintense (Mori), and "Actinostromella" sp. sp. (=Densastroma). The community occurs in the reef limestones of the uppermost Slite Beds on Gotland. Type locality - cliff at Slite cement factory. In Estonia the community has not been discovered due to a stratigraphical gap or unfavourable facies conditions in the Tagavere Beds of the Jaagarahu Formation (Stage). Stromatopora pseudotuberculata was primarily described from the Muksha Formation of Podolia (Riabinin, 1953).

The Labechia conferta Community. A late Wenlock (middle Homerian) community corresponding to BA2. Consists of Labechia conferta Lonsdale, "Clathrodictyon vesiculosum" (sensu Mori, 1970), Stelodictyon striatellum (d'Orbigny), Ecclimadictyon macrotuberculatum (Riabinin), and "Stromatopora antiqua" (sensu Mori, 1970). The community is characteristic of the Halla Beds 
of Gotland, represented by bioclastic, oolitic, and biohermal limestones. Type locality - a rivulet at Backs in central Gotland. The most diagnostic species Labechia conferta and Stelodictyon striatellum occur in the Muksha Formation in Podolia and in the Much Wenlock Limestone of the Welsh Borderland (Nestor \& Nestor, 1991). In the Estonian sequence a subregional hiatus corresponds to the present community (Fig. 2).

The Densastroma pexisum-Petridiostroma simplex Community. A longrange early Wenlock (Sheinwoodian) offshore stromatoporoid community in BA4/5 position, which is characterized by scattered distribution of the nominal species. The community laterally replaces and partly overlaps the Eostromatopora impexa, Vikingia tenuis, Ecclimadictyon astrolaxum, and Stromatopora pseudotuberculata communities, occurring in argillaceous limestones and marlstones of the Upper Visby to Slite beds on Gotland and Jaani to Jaagarahu stages in Estonia. In the uppermost part of the Slite Marl the community is dilated by "Ferestromatopora" insularis Mori, Desmostroma densum (Mori), and Clathrodictyon lenticulare Mori. Type locality - north coast of Stora Carlsö Island, west of Norderhamn. Petridiostroma simplex was described (Parks, 1933) as Clathrodictyon regulare from the La Vieille Formation of the Gaspe Peninsula (see Nestor, 1966). Riabinin (1953) described Densastroma cf. pexisum from the undivided Kitaigorod Group in Podolia.

\section{LUDLOW AND PŘIDOLI COMMUNITIES}

The Araneosustroma stelliparratum Community. An impoverished latest Wenlock-early Ludlow restricted-marine community corresponding to BA1/2. Besides Araneosustroma stelliparratum (Nestor), it includes Ecclimadictyon aff. robustum Nestor and Densastroma podolicum (Yavorsky). The community is sparsely distributed in the interlayers of argillaceous wackestones in the Rootsiküla and Paadla formations of Estonia and, probably, in the Steinsfjorden Formation (9c) of the Holmestrand area in Norway, where an imperfectly preserved Araneosustroma was described by Mori (1978) as Stromatopora sp. Nestor (1981) described Araneosustroma ex gr. stelliparratum and Ecclimadictyon aff. robustum from the upper part of the Middle Klenovsk Formation on Novaya Zemlya where it occurs together with Parallelostroma tenellum, the index species of the contemporaneous reef community described below.

The Parallelostroma typicum-Lophiostroma schmidti Community. An extremely widespread, long-range Ludlow community corresponding to BA3BA4. The most characteristic species of the community are Lophiostroma schmidti (Nicholson), Parallelostroma typicum (Rosen), Plectostroma intermedium (Yavorsky), Densastroma himmestum (Riabinin), and D. podolicum (Yavorsky), but it also includes Petridiostroma convictum (Yavorsky), Ecclimadictyon aff. robustum Nestor, Stromatopora venukovi (Yavorsky), and Stromatopora carteri 
(Nicholson). The community occurs in very variable stratified to nodular bioclastic limestones. It is confined to the Paadla, Torgu, and Kuressaare formations in Estonia and to the Klinteberg to Hamra beds in the Gotland sequence. The type area is between Kihelkonna and Kuressaare in western Saaremaa. Several species of this community (Lophiostroma schmidti, Petridiostroma convictum, Densastroma podolicum, Plectostroma intermedium, Stromatopora venukovi) have been established in the Malinovtsy Group of Podolia (Yavorsky, 1929; Riabinin, 1953; Bol'shakova, 1973; Bogoyavlenskaya in Tsegelnyuk et al., 1983). The community laterally replaces such highly specialized, short-range, reef communities as Parallelostroma tenellum, Stromatopora bekkeri, Simplexodictyon podolicum, Plexodictyon irregulare from one side and the Densastroma densum Community from the other side (Fig. 2).

The Parallelostroma tenellum Community. A diverse latest Wenlock to earliest Ludlow community in BA2 position. Besides the specific taxa Parallelostroma tenellum Mori, Desmostroma balticivaga (Mori), and Oslodictyon botvaldavikense (Mori), the community includes long-range species Ecclimadictyon aff. robustum, Petridiostroma convictum (Yavorsky), Stromatopora venukovi Yavorsky, Stromatopora carteri Nicholson, and Parallelostroma typicum (Rosen), characteristic of the Parallelostroma typicumLophiostroma schmidti Community. The Parallelostroma tenellum Community occurs in the reefs and associated bioclastic rocks of the Klinteberg Beds on Gotland. Type locality - an old quarry at Vivungs in central Gotland. The community laterally replaces the Araneosustroma stelliparratum Community from one side and the Parallelostroma typicum-Lophiostroma schmidti Community from the other side.

The Stromatopora bekkeri Community. An early Ludlow (Gorstian) reef community corresponding to BA2 and replacing the Parallelostroma typicumLophiostroma schmidti Community shoreward. Besides the long-range species of the latter community, it includes some specific taxa: Stromatopora bekkeri Nestor, "Stromatopora" lamellosa Yavorsky, and Clathrodictyon mohicanum Nestor. The community is distributed in biohermal and associated limestones of the Sauvere Beds of the Paadla Formation (Stage) in Estonia and in the lower part of the Hemse Beds in eastern Gotland. Type locality - old quarries at Riiumägi, western Saaremaa. In Podolia Clathrodictyon mohicanum has been identified from the Konovka Formation of the Malinovtsy Group (Bogoyavlenskaya in Tsegelnyuk et al., 1983), while "Stromatopora" lamellosa spreads there throughout the Malinovtsy Group.

The Simplexodictyon podolicum Community. A very rich middle Ludlow (early Ludfordian) community confined to the reef facies and corresponding to BA2. The community laterally replaces the Parallelostroma typicumLophiostroma schmidti Community. Besides the most common species of the latter community, it contains many specific taxa such as Simplexodictyon podolicum (Yavorsky), Yabeodictyon quebecense (Stearn et Hubert), Plexodictyon 
katriense Nestor, Plectostroma mirificum Nestor, P. atterdagi Mori, P. lepidum (Mori), Pseudolabechia granulata Yabe et Sugiyama, Syringostromella borealis (Nicholson), and Clavidictyon? sp. The community is characteristic of the bioherms, biostromes, and associated rocks of the Uduvere Beds of the Paadla Formation (Stage) and of the upper part of the Hemse Beds in eastern Gotland. Type locality - Katri cliff on the west coast of Saaremaa. Simplexodictyon podolicum and Syringostromella borealis have been found in Podolia, where they occur in the Konovka Formation of the Malinovtsy Group (Yavorsky, 1929; Bol'shakova, 1973). Nestor (1981) identified Simplexodictyon podolicum from the Zapadno Khatanzei Formation of Novaya Zemlya. Birkhead (1976) recognized the same species from the Hume Limestone Member of the Silverdale Formation in the Yass area of New South Wales, Australia. Savelle (1979) described the same species under the name Diplostroma sp., and Plexodictyon katriense from the Red Bay Formation of Somerset Island, arctic Canada. Densastroma podolicum and Syringostromella borealis occur in the Xibiehe Formation in Inner Mongolia (Dong, 1984).

The Plexodictyon irregulare Community. A specific late Ludlow (late Ludfordian) reef community corresponding to BA2. The community laterally replaces and partly overlaps the Parallelostroma typicum-Lophiostroma schmidti Community. It is characterized by Plexodictyon irregulare Mori, Plectostroma scaniense Mori, Stromatopora clarkei Parks, "Parallelopora" ornata Mori, and Densastroma cf. sociale (Riabinin), but long-range, widespread Parallelostroma typicum (Rosen), Lophiostroma schmidti (Nicholson), and Ecclimadictyon aff. robustum are present too. The community is distributed in reefs and related rocks of the Ventspils Formation in Latvia and Lithuania (author's unpublished data), and in the Öved-Ramsåsa Group of Scania, Sweden (Mori, 1969). A less diverse variety of this community, including Plectostroma scaniense, Lophiostroma schmidti, Parallelostroma typicum, "Parallelopora" ornata, and Clavidictyon? sokolovi Mori, is distributed in the Eke, Hamra, and Sundre beds of Gotland. The type section of the community is the interval of $420.0-458.3 \mathrm{~m}$ in the Ventspils drill core (northwestern Latvia). Stromatoporoids are the main frame builders in the large Ventspils bioherms (Nestor, 1995). The characteristic elements of the Plexodictyon irregulare Community have not been established in the Estonian sections. On the approximately same stratigraphical level (Kuressaare Formation) the Parallelostroma typicum-Lophiostroma schmidti Community is distributed. Densastroma sociale has been described from the upper part of the Malinovtsy Group and from the lower part of the Skala Group in Podolia (Riabinin, 1953; Bol'shakova, 1973). Stromatopora clarkei was originally described from the Rondout Formation (Přidoli) in central New York (Parks, 1909; Stock, 1979).

The Densastroma densum Community. A distal, offshore latest Wenlock to Ludlow community corresponding to BA4/5. The community includes Densastroma densum (Mori), Actinostromella aff. vaiverensis Nestor, and 
Clathrodictyon aff. sulevi Nestor. It is distributed in marlstones of the Mulde Beds (upper Wenlock) and in the Hemse Marls (Ludlow). In the former unit Stelodictyon? djupvikense (Mori) is added, while in the Hemse Marls Parallelostroma dnestriense (Riabinin) and P. maestermyrense Mori complement the species assemblage. Type locality - a road ditch at Mästermyr in western Gotland. The community has not been discovered in other areas. It has a very long stratigraphical range and laterally replaces the Parallelostroma typicumLophiostroma schmidti Community (Fig. 2).

The Actinostromella vaiverensis Community. An inadequately studied, scattered early Prridoli community corresponding to BA3-BA4. Besides the nominal species it contains Parallelostroma kaugatomicum (Riabinin), as well as Plectostroma scaniense and Densastroma cf. sociale which pass over from the lower-lying strata. The community mainly occurs in argillaceous biomicritic limestones of the Lower Äigu Beds of the Kaugatuma Formation (Stage) on Saaremaa. Type area - the surroundings of Muratse on the south coast of Saaremaa. The lateral equivalents of the community are obscure. Parallelostroma kaugatomicum has been identified from the Rondout Formation (Přidoli) in central New York (Stock, 1979) and from the upper part of the Keyser Formation in Virginia (Stock \& Holmes, 1986).

The Parallelostroma tuberculatum Community. A poorly represented early-middle Prridoli community in BA2 position, dominated by Parallelostroma tuberculatum (Yavorsky), P. minosi Nestor, P. kaugatomicum (Riabinin), and Densastroma astroites (Rosen), but also containing unique Plectostroma schmidti (Rosen) and Pachystylostroma sp. The community is characteristic of the crinoidal limestones of the Upper Äigu Beds of the Kaugatuma Formation. It occurs stratigraphically higher in the sequence than the Actinostromella vaiverensis Community but the differences between these communities may also be due to environmental conditions. Type locality - an old quarry at VäikeRootsi on the Vätta Peninsula of Saaremaa. Parallelostroma tuberculatum and Densastroma astroites have been recorded from different parts of the Malinovtsy and Skala groups in Podolia (Yavorsky, 1929; Riabinin, 1953; Bol'shakova, 1973), but some of these identifications are doubtful.

\section{SUMMARY AND CONCLUSIONS}

Stromatoporoids were distributed in the normal-marine carbonate-platform environments, mainly in the shoal and open shelf facies belts of the Palaeobaltic Basin. Rare, scattered occurrences of a few long-range taxa are recorded in the adjacent, lagoonal (restricted shelf) and transition facies belts. The successive stromatoporoid faunas consist of rather indistinctly delimited lateral communities corresponding to the Standard Benthic Assemblages BA1/2 to BA4/5 by Boucot 
(1975). The richest, most diverse communities corresponding to BA2 occurred in the reef environments of the shoal facies belt. They include specific short-range taxa, which enables more detailed biozonation of the sequences of the shoal facies than of the other facies belts. The marginal stromatoporoid communities in BA1/2 and BA4/5 positions stand out because of the impoverished taxonomic content of long-range species among which representatives of the fineststructure, microreticulate stromatoporoids prevail (Densastroma, Desmostroma, Araneosustroma, Actinostromella). During the late Ordovician and Silurian, a gradual diversification and enrichment of stromatoporoid communities took place. Maximum values were reached in the open shelf environments by the early Telychian (Clathrodictyon variolare Community) and in the shoal environments by the early Ludfordian (Simplexodictyon podolicum Community). The characteristic elements of these communities have also the widest geographical distribution.

\section{ACKNOWLEDGEMENTS}

I am very grateful to Björn Neuman from the University of Bergen who guided the field trips to Gotland Island (1994) and the Oslo Region (1995 and 1997), and to Viiu Nestor for improving the correlation of the Estonian, Gotland, and Norwegian sequences by chitinozoans. Many thanks to Kaie Ronk for the illustrations. This research was supported by the Estonian Science Foundation (grant No. 1665). The field works were financed from the scientific exchange funds of the Swedish and Norwegian Royal Academies of Sciences.

\section{REFERENCES}

Birkhead, P. K. 1976. Silurian stromatoporoids from Cheesmans Creek, with a survey of some stromatoporoids from the Hume Limestone Member, Yass, New South Wales. Rec. Geol. Surv. New South Wales, 17, 2, 87-122.

Bogoyavlenskaya, O. V. 1973. Silurijskie stromatoporoidei Urala. Nauka, Moscow (in Russian).

Bol'shakova, L. N. 1973. Stromatoporoidei silura i nizhnego devona Podolii. Trudy Paleont. Inst., 141 (in Russian).

Boucot, A. J. 1975. Evolution and Extinction Rate Controls. Elsevier, Amsterdam.

d'Orbigny, A. 1849. Prodrôme de Paléontologie. Stratigraphique universielle des animaux mollusques et rayonnés. T. 1. Masson, Paris.

Dong, D. Y. 1984. Silurian and Lower Devonian stromatoporoids from Darhan Mumigan Joint Banner, Inner Mongolia. In Silurian and Devonian Rocks and Faunas of the Bateaobao Area in Darhan Mumigan Joint Banner, Inner Mongolia (Li, W. G., Rong, J. Y. \& Dong, D. Y., eds.), pp. 57-77. The Peoples' Publishing House of Inner Mongolia (in Chinese).

Galloway, J. J. \& St. Jean, J. Jr. 1961. Ordovician Stromatoporoidea of North America. Bull. Amer. Paleont., 43, 194. 
Kaljo, D., Klaamann, E. \& Nestor, H. 1963. Features in common in the Ashgillian coral and stromatoporoid faunas of Estonia and Norway. ENSV TA Geol. Inst. Uurimused, 13, 75-81 (in Russian).

Lin, B. Y. \& Webby, B. D. 1988. Clathrodictyid stromatoporoids from the Ordovician of China. Alcheringa, 12, 233-247.

Männil, R. \& Meidla, T. 1994. The Ordovician System of the East European Platform (Estonia, Latvia, Lithuania, Byelorussia, parts of Russia, the Ukraine and Moldova). In The Ordovician System of the East European Platform and Tuva (Southeastern Russia) (Webby, B. D., Ross, R. J. \& Zhen, Y. Y., eds.). IU Geol. Sci. Publ., 28.

Mori, K. 1968. Stromatoporoids from the Silurian of Gotland. Part 1. Stockholm Contrib. Geol., 19.

Mori, K. 1969. Stromatoporoids from the Upper Silurian of Scania, Sweden. Stockholm Contrib. Geol., 21, 3, 43-52.

Mori, K. 1970. Stromatoporoids from the Silurian of Gotland. Part 2. Stockholm Contrib. Geol., 22.

Mori, K. 1978. Stromatoporoids from the Silurian of the Oslo Region, Norway. Norsk Geol. Tidsskr., 58, 121-144.

Nestor, H. 1964. Stromatoporoidei ordovika $i$ llandoveri Éstonii. Institut geologii AN ÉSSR, Tallinn (in Russian).

Nestor, H. 1966. Stromatoporoidei venloka i ludlova Éstonii. Valgus, Tallinn (in Russian).

Nestor, H. 1976. Rannepaleozojskie stromatoporoidei basseina reki Moiero (sever Sibirskoj platformy). Valgus, Tallinn (in Russian).

Nestor, H. 1977. On the ecogenesis of the Palaeozoic stromatoporoids. Mem. Bur. Rech. Geol. Min., 89, 249-254.

Nestor, H. 1981. Stromatoporoids. In Ob"yasnitel'naya zapiska $k$ skheme stratigrafii verkhnesilurijskikh otlozhenii Vajgachko-Yuznonovozemel'skogo regiona, pp. 97-107. Leningrad (in Russian).

Nestor, H. 1982. The Baltic middle Silurian stromatoporoid succession. In Ecostratigraphy of the East Baltic Silurian (Kaljo, D. \& Klaamann, E., eds.), pp. 43-49. Valgus, Tallinn.

Nestor, H. 1983. Stromatoporaty. In Ob"yasnitel'naya zapiska $k$ skheme stratigrafii nizhnesilurijskikh otlozhenij yuga Novoj Zemli, pp. 48-52. Leningrad (in Russian).

Nestor, H. 1984. Autecology of stromatoporoids in Silurian cratonic seas. Spec. Pap. Palaeont., 32, 265-280.

Nestor, H. 1990. Stromatoporoids. In Field Meeting Estonia 1990. An Excursion Guidebook. (Kaljo, D. \& Nestor, H., eds.), pp. 46-51. Tallinn.

Nestor, H. 1995. Ordovician and Silurian reefs in the Baltic area. Publ. Serv. Geol. Luxembourg, 29, 39-47.

Nestor, H. 1997. Silurian. In Geology and Mineral Resources of Estonia (Raukas, A. \& Teedumäe, A., eds.), pp. 89-106. Estonian Academy Publishers, Tallinn.

Nestor, H. 1999. Telychian (Lower Silurian) stromatoporoids from Charlestown Inlier, County Mayo, Ireland. Ir. J. Earth Sci. (in press).

Nestor, V. \& Nestor, H. 1991. Dating of the Wenlock carbonate sequences in Estonia and stratigraphic breaks. Proc. Estonian Acad. Sci. Geol., 40, 2, 50-60.

Nicholson, H. A. 1886. On some new or imperfectly-known species of stromatoporoids. Pt. 1. Ann. Mag. Nat. Hist., 5, 17, 225-239.

Owen, A. W., Bruton, D. L., Bockelie, J. F. \& Bockelie, T. G. 1990. The Ordovician succession of the Oslo Region, Norway. Norges Geol. Unders. Spec. Publ., 4.

Parks, W. A. 1909. Silurian stromatoporoids of America (exclusive of Niagara and Guelph). Univ. Toronto Studies Geol. Ser., 6.

Parks, W. A. 1933. New species of stromatoporoids, sponges, and corals from the Silurian strata of Baie des Chaleurs. Univ. Toronto Studies Geol. Ser., 33.

Petryk, A. A. 1967. Some Silurian stromatoporoids from northwestern Baffin Island, District of Franklin. Geol. Surv. Can. Pap., 67, 7. 
Riabinin, V. N. 1951. Stromatoporoidei Éstonskoj SSR (silur i verkhi ordovika). Trudy Vses. neft. nauch.-issl. geologorazv. inst. (VNIGRI), Nov. ser., 43 (in Russian).

Riabinin, V.N. 1953. Silurijskie stromatoporoidei Podolii. Trudy Vses. neft. nauch.-issl. geologorazv. inst. (VNIGRI), Nov. ser., 67 (in Russian).

Rosen, F. 1867. Über die Natur der Stromatoporen und über die Erhaltung der Hornfasern der Spongien im fossilen Zustande. Verh. Russ.-Kais. Miner. Ges. St. Petersburg, 2, 4.

Savelle, J. M. 1979. Upper Silurian stromatoporoids from Somerset Island, Arctic Canada. Can. J. Earth Sci., 16, 2, 364-372.

Schmidt, F. 1858. Untersuchungen über die silurische Formation von Ehstland, Nord-Livland und Oesel. Arch. Naturk. Liv-, Ehst- u. Kurlands, 1, 2, 1.

Stearn, C. W. \& Hubert, C. 1966. Silurian stromatoporoids of the Matapedia-Temiscouata area, Quebec. Can. J. Earth Sci., 3, 31, 31-48.

Stearn, C. W., Webby, B. D., Nestor, H. \& Stock, C. W. 1999. Revised classification and terminology of Palaeozoic stromatoporoids. Acta Palaeont. Polon., 44, 1.

Stock, C. W. 1979. Upper Silurian (Pridoli) Stromatoporoidea of New York. Bull. Amer. Paleont., 76, 308.

Stock, C. W. \& Holmes, A. E. 1986. Upper Silurian/Lower Devonian Stromatoporoidea from the Keyser Formation at Mustoe, Highland County, west-central Virginia. J. Paleont., 60, 3, 555-580.

Tsegelnyuk, P. D., Gritsenko, V. P., Konstantinenko, L. I. et al. 1983. The Silurian of Podolia. The Guide to Excursion. Naukova Dumka, Kiev.

Webby, B. D. 1969. Ordovician stromatoporoids from New South Wales. Palaeontology, 12, 4, 637-662.

Webby, B. D. 1979. Ordovician stromatoporoids from the Mjøsa district, Norway. Norsk Geol. Tidsskr., 59, 3, 199-211.

Worsley, D., Aarhus, N., Bassett, M. G., Howe, P. A., Mork, A. \& Olaussen, S. 1983. The Silurian succession of the Oslo Region. Norges Geol. Unders., 384 (Bull. 72).

Yavorsky, V. I. 1929. Silurijskie Stromatoporoidea. Izv. Geol. komiteta, 48, 1, 77-144.

Yavorsky, V. I. 1961. Stromatoporoidea Sovetskogo Soyuza. 3. Trudy Vses. nauchno-issled. geol. inst. (VSEGEI), Nov. ser., 44 (in Russian).

\section{BALTOSKANDIA VARAPALEOSOIKUMI STROMATOPOORI- KOOSLUSTE STRUKTUUR JA SUKTSESSIOON}

\section{Heldur NESTOR}

On defineeritud 28 stromatopoorikooslust, mis levivad Eesti, Rootsi (Gotland) ja Norra (Oslo piirkond) ülemordoviitsiumi ja siluri setendites. Kooslused on seotud Boucot' (1975) standardsete bentose assotsiatsioonidega (BA). Üksteisele järgnevad stromatopoorifaunad koosnevad ebaselgelt piiritletud lateraalsetest kooslustest, mis erinevad stratigraafilise ulatuse ja taksonoomilise mitmekesisuse poolest. Kõige rikkamad ja lühima kestusega kooslused esinevad rannamadala vööndi rififaatsieses, mis vastab bentose assotsiatsioonile BA2. Lateraalselt asenduvad need kooslused liigivaesemate ja pikema stratigraafilise levikuga kooslustega. 


\title{
СТРУКТУРА И ПОСЛЕДОВАТЕЛЬНОСТЬ СООБЩЕСТВ РАННЕПАЛЕОЗОЙСКИХ СТРОМАТОПОРОИДЕЙ БАЛТОСКАНДИИ
}

\author{
Хелдур НЕСТОР
}

Приведены определения 28 сообществ строматопороидей, распространенных в верхнеордовикских отложениях Эстонии, Швеции (о-в Готланд) и Норвегии (район Осло). Сообщества связаны со стандартными бентосными ассоциациями (ВА) по Буко (1975). Последовательные строматопоровые фауны состоят из неотчетливо разграниченных латеральных сообществ, имеющих различную стратиграфическую протяженность и видовое разнообразие. Наиболее богатые по составу сообщества встречаются в рифовой фации, соответствующей бентосной ассоциации BA2. Этим сообществам свойственны наименьшая стратиграфическая протяженность и латеральное замещение менее разнообразными и долгосуществовавшими сообществами. 